DOI: 10.35784/IAPGOS.63

\title{
APPLICATION OF ARTIFICIAL NEURAL NETWORK IN THE PROCESS OF SELECTION OF ORGANIC COATINGS
}

\author{
Artur Popko, Konrad Gauda \\ University of Economics and Innovation in Lublin, Faculty of Transport and Computer Department of Transport and Computer Science, Lublin, Poland
}

Abstract. The structure of the artificial neural network (ANN) to support the selection of organic coatings was developed and verified, and its learning process was carried out. A simulation of the operation of the network was also carried out, which showed that programming of the coating system selection process can be much faster and more accurate, which is important for a system used in industrial conditions.

Keywords: artificial neural network, organic coatings

\section{ZASTOSOWANIE SZTUCZNEJ SIECI NEURONOWEJ W PROCESIE DOBORU POWLOK ORGANICZNYCH}

Streszczenie. Opracowano i zweryfikowano strukturę sztucznej sieci neuronowej (SSN) stużacej do wspomagania procesu doboru powłok organicznych
oraz przeprowadzono jej proces uczenia. Dokonano również symulacji działania przedmiotowej sieci, która wykazała, że programowanie procesu doboru systemu powłokowego może być o wiele szybsze i dokładniejsze, co ma istotne znaczenie dla systemu użtkowanego w warunkach przemystowych.

Slowa kluczowe: sztuczna sieć neuronowa, powłoki organiczne

\section{Introduction}

When choosing the type of protective and decorative coatings, it is particularly important to analyse the operational requirements determining the main destructive factors occurring during the use of the coating. Factors that determine the choice of coating type are primarily: the corrosive aggressiveness of the environment, the type of protected structure, the required degree of surface preparation, the life expectancy, the data of paint thickness limits, and data on the environment during application, etc. A comprehensive and meticulous analysis of all necessary data can be supported by an IT system based on an artificial neural network. Thanks to such a tool, programming of the coating system selection process can be much faster and more accurate.

\section{Rules for the selection of protective and decorative coatings}

The first stage when choosing paint sets should be the analysis of the operational requirements for coatings depending on the type of objects to be covered. These requirements determine the main destructive, climatic and corrosive factors occurring during operation, which decide the choice of coating [1-5].

Knowing the initial operating requirements for coatings to protect a particular object, you can proceed to the next selection stages. This selection, however, is very complex due to the need to take into account both the requirements for decorativeness and the coating's resistance to the effects of simultaneously occurring climatic and corrosive factors. In this selection, the size of the object, the material used for its manufacture, the method of assembly and the total cost of protection are also important. Therefore, the selection of a coating system for corrosion protection should be the result of a full technical and economic analysis $[2,9]$.

General rules for the selection of paint coatings are included in the relevant standards $[6,7]$. Operating conditions were divided there into various macroclimate and microclimate taking into account additional factors (dust, steam, gases, and electrolytes), as well as corrosive aggressiveness of the environment and operational exposures: mechanical, temperature, physicochemical and biological. Most often, preliminary decisions regarding the choice of coverings are made just depending on environmental and operational exposures. The division and marking of exposures to products during exploitation that facilitate the selection of paint coatings is presented in Table 1 .
Table 1. Selection of coatings depending on environmental exposures $[9,11]$

\begin{tabular}{|c|c|c|c|c|c|c|c|}
\hline \multirow{2}{*}{$\begin{array}{c}\text { Environmental } \\
\text { exposures }\end{array}$} & \multicolumn{7}{|c|}{ Type of resin } \\
\cline { 2 - 9 } & $\mathrm{AK}$ & $\mathrm{CHK}$ & $\mathrm{PCW}$ & $\mathrm{ER}$ & $\mathrm{PU}$ & $\mathrm{SI}$ & $\mathrm{AR}$ \\
\hline $\begin{array}{c}\text { Rural and urban } \\
\text { environment }\end{array}$ & + & + & + & $\mathrm{o}$ & - & $\mathrm{o}$ & $\mathrm{o}$ \\
\hline $\begin{array}{c}\text { Acidic industrial } \\
\text { environment }\end{array}$ & $\mathrm{o}$ & + & + & + & 0 & - & - \\
\hline Alkaline environment & $\mathrm{o}$ & + & + & + & + & - & + \\
\hline $\begin{array}{c}\text { Acidic chemical } \\
\text { environment }\end{array}$ & - & + & + & 0 & + & - & + \\
\hline $\begin{array}{c}\text { Chemical environment } \\
\text { with traces of solvents }\end{array}$ & - & 0 & 0 & + & 0 & - & + \\
\hline $\begin{array}{c}\text { Water action }- \\
\text { immersion }\end{array}$ & - & + & + & + & + & - & + \\
\hline Water condensation & 0 & + & + & + & + & - & + \\
\hline Temperature $80^{\circ} \mathrm{C}$ & + & + & + & + & + & + & + \\
\hline Temperature $80 \div 140^{\circ} \mathrm{C}$ & + & - & - & + & + & + & + \\
\hline $\begin{array}{c}\text { Temperature } \\
140 \div 200^{\circ} \mathrm{C}\end{array}$ & - & - & - & + & + & + & + \\
\hline
\end{tabular}

*AK-alkyd; CHK - chlorinated rubber; PCW - polyvinyl chloride; ER-epoxy;

$\mathrm{PU}$ - polyurethane; SI - silicone; AR - acrylic; + suitable; o sometimes suitable; - unsuitable

Epoxy paint has the most favourable properties. It is also worth paying attention to polyurethane and acrylic paints, which in addition to high temperature resistance and various corrosive environments are characterized by decorative properties, which is of great importance, e.g. in the automotive industry.

It should be noted, however, that these types are general. The durability and protective properties of the coating are determined not only by the film-forming resin but also to a large extent by other ingredients, primarily pigments [13, 14].

A comprehensive analysis of all necessary data can be supported by an IT system based on an artificial neural network. Thanks to such a tool, programming of the coating system selection process can be much faster and more accurate, especially in conditions when not all data is available, and therefore in industrial conditions.

\section{Design of artificial neural network structure}

As already mentioned, the analysis of necessary data can be supported by an IT system based on an artificial neural network. Boundary parameters for the ANN structure and their interrelationship were determined (Table 2). 
Input parameters for ANN:

- Mechanical exposure (abrasion, impact, scratching) (0 - none, 1 - small, 2 - medium, 3 - large).

- Chemical exposure $(0-$ no exposure, $1-$ contact with acids, 2 - contact with bases, 3 - contact with hydrocarbon solvents).

- Biological exposures ( 0 - no exposure, 1 - exposure caused by mould, bacteria, 2 - exposure caused by organisms, algae).

- Water action (humidity) (0- none, $1-$ low, $2-$ high, 3 -immersion).

- Environment (0 - rural, 1 - urban, 2 - industrial, 3 - coastal).

- Corrosiveness of the atmosphere $(0-$ low, 1 - moderate, 2 - high, 3 - very high).

- Operating temperature $\left(0-\right.$ up to $80{ }^{\circ} \mathrm{C}, 1-80-140^{\circ} \mathrm{C}$, $2-140-200^{\circ} \mathrm{C}, 3-$ above $\left.200^{\circ} \mathrm{C}\right)$.

- Decorativeness of the coating ( 0 - no, $1-$ yes $)$.

- Substrate type $(0-$ steel, 1 - non-ferrous metals, 2 - wood, 3 - plastic).

Output parameters for ANN:

Choice of coating type (set number):

1 - alkyd, 2 - acrylic, 3 - waterborne acrylic (ecological), 4 - chlorinated rubber, 5 - epoxy, 6 - polyurethane, 7 - polyvinyl chloride, 8 -silicone.

Table 2. Relationship of I/O parameters [1, 11]

\begin{tabular}{|c|c|c|c|c|c|c|c|c|c|}
\hline \multirow[b]{2}{*}{ 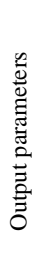 } & \multicolumn{9}{|c|}{ Input parameters } \\
\hline & 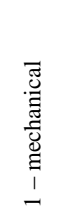 & 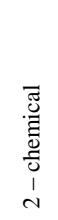 & $\begin{array}{l}\overline{7} \\
.00 \\
00 \\
0 \\
0 \\
0 \\
1 \\
m\end{array}$ & $\begin{array}{l}\bar{\omega} \\
\tilde{N} \\
\vdots \\
1 \\
+\end{array}$ & 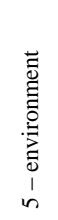 & 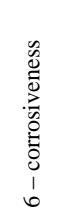 & 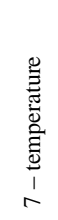 & 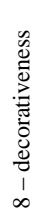 & 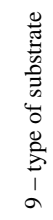 \\
\hline $\begin{array}{c}1 \\
\mathrm{AK}\end{array}$ & 0,1 & 0 & 0 & 0,1 & 0,1 & 0,1 & 0,1 & 1 & $\begin{array}{r}0,1, \\
2,3\end{array}$ \\
\hline $\begin{array}{c}2 \\
\mathrm{AR}\end{array}$ & $\begin{array}{c}0,1, \\
2\end{array}$ & $\begin{array}{l}0,1, \\
2,3\end{array}$ & 0 & $\begin{array}{l}0,1, \\
2,3\end{array}$ & $\begin{array}{c}0,1, \\
2\end{array}$ & $\begin{array}{c}0,1, \\
2\end{array}$ & $\begin{array}{c}0,1, \\
2\end{array}$ & 1 & $\begin{array}{r}0,1, \\
2,3\end{array}$ \\
\hline $\begin{array}{c}3 \\
\text { AR } \\
\text { w }\end{array}$ & 0,1 & $\begin{array}{c}0,1 \\
2\end{array}$ & 0 & 0 & 0,1 & 0 & 0,1 & 1 & $\begin{array}{c}1,2, \\
3\end{array}$ \\
\hline $\begin{array}{c}4 \\
\mathrm{CH} \\
\mathrm{K}\end{array}$ & 0,1 & $\begin{array}{c}0,1 \\
2\end{array}$ & 0 & $\begin{array}{l}0,1, \\
2,3\end{array}$ & $\begin{array}{l}0,1, \\
2,3\end{array}$ & $\begin{array}{c}1,2 \\
3\end{array}$ & 0 & 1 & $\begin{array}{r}0,1, \\
2,3\end{array}$ \\
\hline $\begin{array}{c}5 \\
\text { ER }\end{array}$ & $\begin{array}{c}0,1, \\
2\end{array}$ & $\begin{array}{l}0,1, \\
2,3\end{array}$ & $\begin{array}{c}0,1, \\
2\end{array}$ & $\begin{array}{l}0,1, \\
2,3\end{array}$ & $\begin{array}{c}0,1, \\
2,3\end{array}$ & $\begin{array}{c}1,2 \\
3\end{array}$ & 0,1 & 0 & $\begin{array}{r}0,1, \\
2,3\end{array}$ \\
\hline $\begin{array}{c}6 \\
\mathrm{PU}\end{array}$ & $\begin{array}{l}0,1, \\
2,3\end{array}$ & $\begin{array}{c}0,2 \\
3\end{array}$ & $\begin{array}{c}0,1, \\
2\end{array}$ & $\begin{array}{r}0,1, \\
2,3\end{array}$ & $\begin{array}{c}1,2 \\
3\end{array}$ & $\begin{array}{c}1,2 \\
3\end{array}$ & 0,1 & 1 & $\begin{array}{r}0,1, \\
2,3\end{array}$ \\
\hline $\begin{array}{c}7 \\
\text { PC } \\
W\end{array}$ & $\begin{array}{c}0,1 \\
2\end{array}$ & 0,2 & 0 & $\begin{array}{l}0,1, \\
2,3\end{array}$ & $\begin{array}{l}0,1, \\
2,3\end{array}$ & 2,3 & 0 & 1 & $\begin{array}{l}0,1, \\
2,3\end{array}$ \\
\hline $\begin{array}{c}8 \\
\text { SI }\end{array}$ & $\begin{array}{c}0,1, \\
2\end{array}$ & 0 & 0 & 0,1 & 0,1 & 0,1 & 2,3 & 1 & $\begin{array}{l}0,1, \\
2,3\end{array}$ \\
\hline
\end{tabular}

On this basis, it was possible to develop the initial form of the artificial neural network structure required to support the selection of protective and decorative coatings (Fig. 1). The input and output data vectors specify the number of neurons in the input and output layers. The hidden ANN layer consists of neurons that are between the input layer and the output layer, and their number and organization can be treated as a "black box". Using additional layers of hidden neurons enables greater processing efficiency and increases the flexibility of the ANN system. This additional flexibility, however, increases the cost of complexity in the training algorithm. Too few hidden neurons, on the other hand, can prevent the system from properly matching the input data and reduce its resistance $[8-10,12]$. Therefore, research was carried out to determine the optimal, final ANN structure and it was verified.

The required structure of the artificial neural network was developed in the MemBrain application environment.

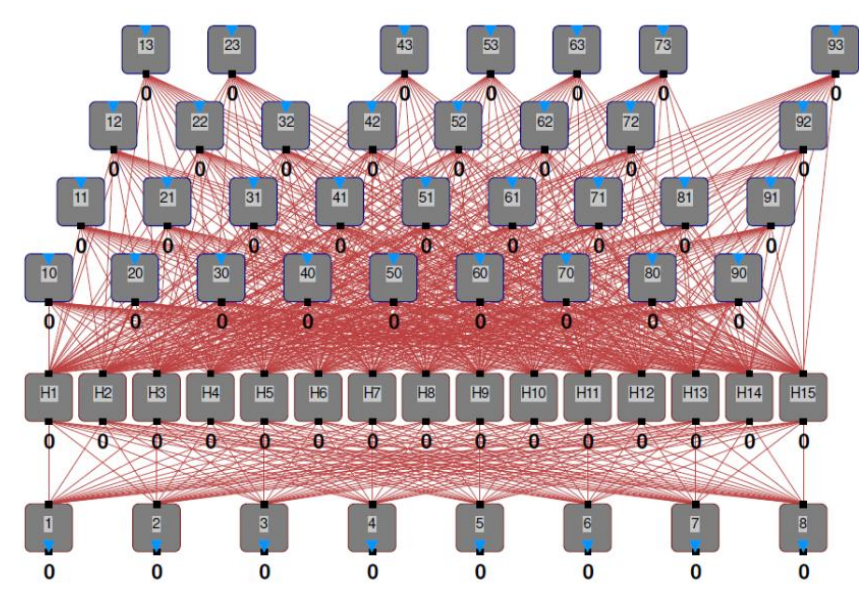

Fig. 1. Structure of the designed artificial neural network

\section{The neural network learning process}

The essence of the article was to determine and optimize the structure of the neural network, supporting the process of selecting organic coatings. The network's task will be to recognize eight visual patterns adequate to the types of organic coatings. The input and output vectors were generated using the "lesson editor" tool (Fig. 2). An example visualization of one pattern is shown in Figure 3. A training algorithm was used - standard backward propagation. The target network error was set at 0.01 (Fig. 4). To achieve proper results when teaching the network, it must be randomized beforehand - during the first teaching process. Network randomization means that all link weights and activation thresholds for neurons are initiated with small, randomly generated values (unless the corresponding connection or neuron properties are blocked). The values of errors made by the network during its learning were monitored using the "Net error viewer" tool (Fig. 5).

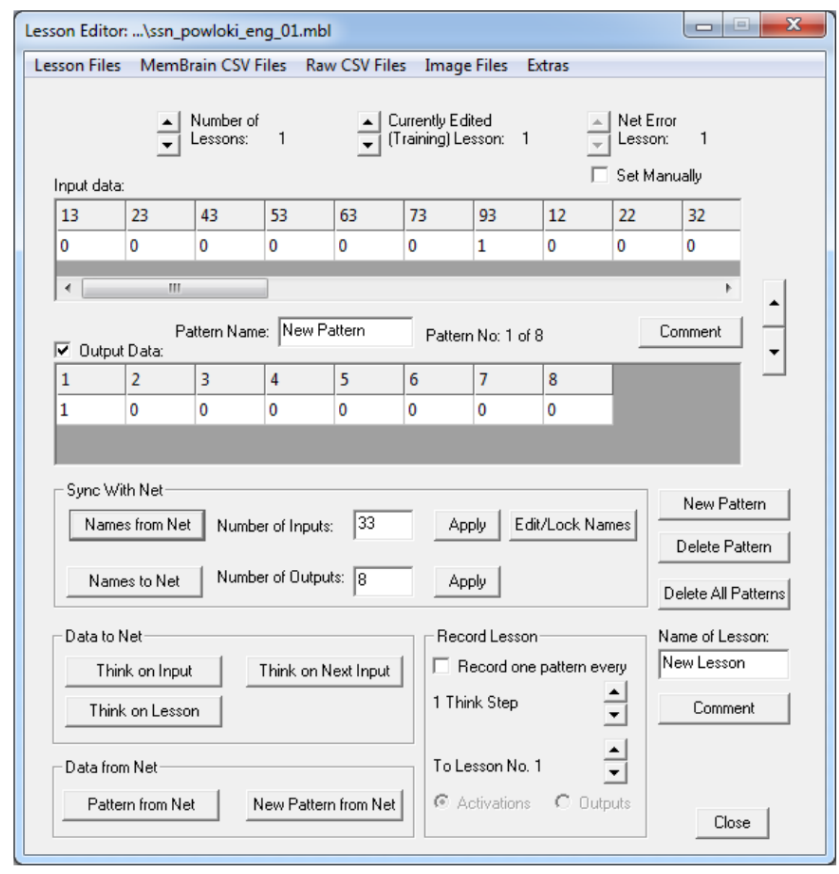

Fig. 2. View of the "lesson editor" tool 


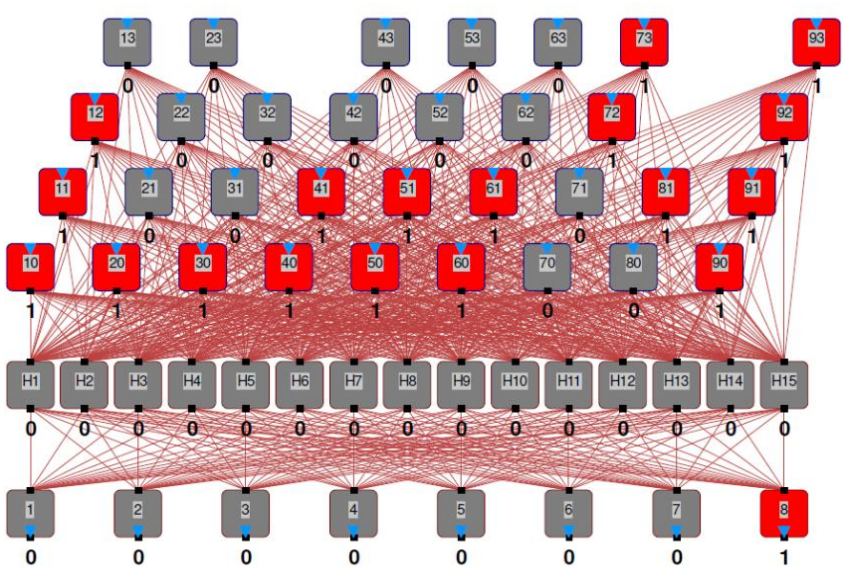

Fig. 3. Visualization of an exemplary vector pattern (silicone coating)

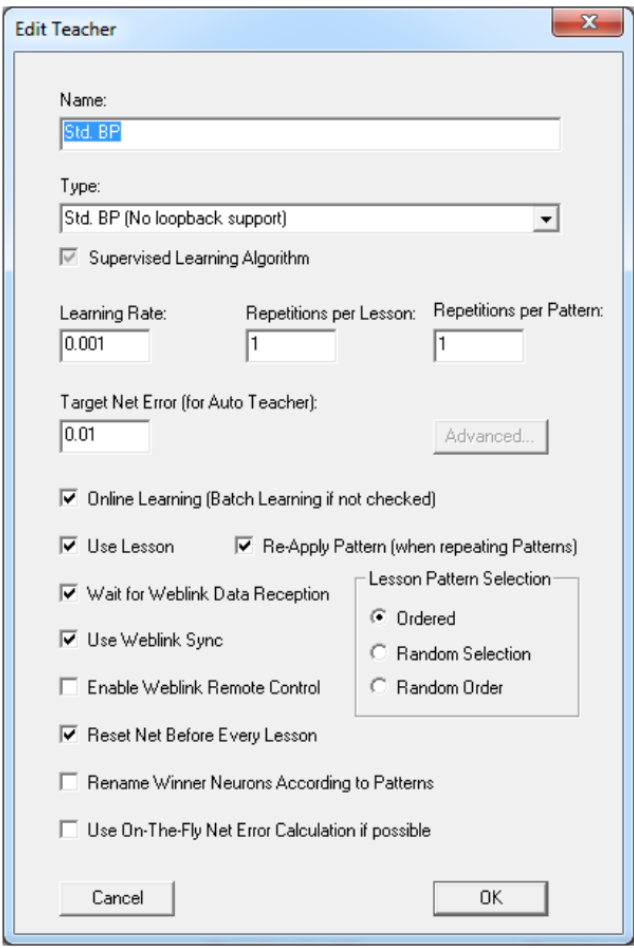

Fig. 4. View of the "Edit Teacher" tool

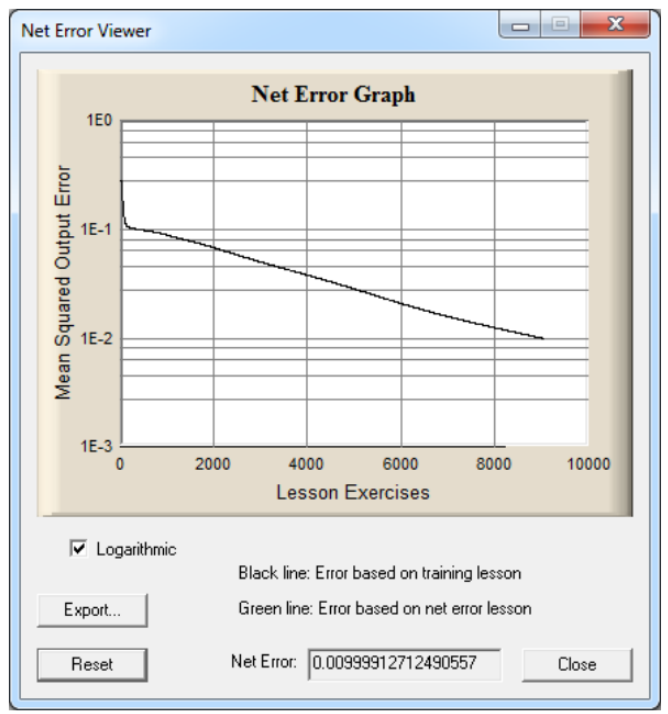

The next stage of research was testing the network with the number of 4-30 neurons in the hidden layer. The results of ANN structure optimization are shown in Figure 6. A better result is obtained when the neural network requires less training cycles. The final resulting relationship between the number of exercises and the number of neurons in the hidden layer is shown in Figure 6. The most effective architecture of the tested ANN consists of 10 neurons in a hidden layer.

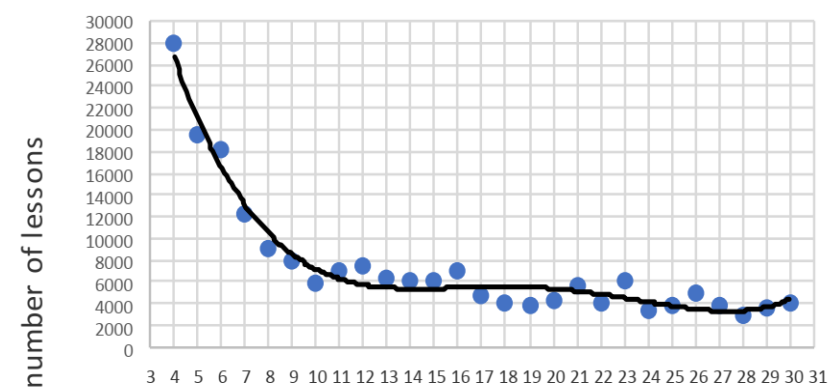

number of neurons

Fig. 6. Results of ANN structure optimization

\section{Simulation of the network operation}

The developed and tested neural network recognizes visual patterns flawlessly. The example presented in Figure 7 relates to supporting the process of selecting organic coatings when the input data is not complete. For the assumed task input parameters, the neural network indicates the solution, which consists in choosing a silicone coating.

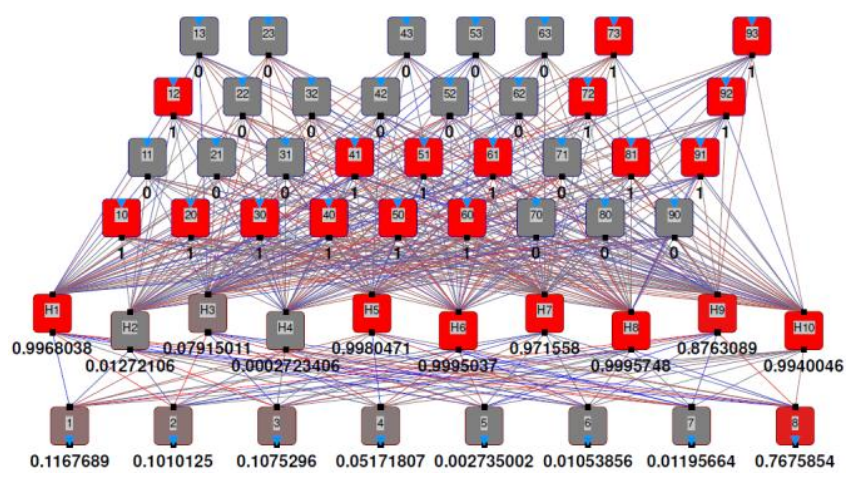

Fig. 7. An example of supporting the process of selecting organic coatings

\section{Summary}

An artificial neural network project was developed to support the selection of organic coatings. The most adequate initial architecture of the studied ANN consists of 51 neurons, of which 10 contained in a hidden layer. The developed form of an artificial neural network was based on a structure containing only one hidden layer of neurons of the type of standard back propagation without feedback. Network learning was carried out using the "with the teacher" method with the target network error adopted. The learning process was carried out based on a sequential system, using appropriate standards.

The conducted research shows that the adopted assumptions are fully correct. The developed and verified form of the artificial neural network supports solving the problem of choosing the type of organic protective and decorative coatings in a highly effective manner. In addition, the problems described in the study, and in particular the methodology for the implementation of artificial neural networks in the presented range can be successfully used to support similar processes. 


\section{References}

[1] Gauda K.: Wodorozcieńczalne powłoki organiczne w przemyśle maszynowym. Lubelskie Towarzystwo Naukowe, Lublin 2011.

[2] Gauda K., Lenik K., Zinowicz Z.: The possibility of use of waterborne epoxy coatings for the protection of machine and device elements. International Conference: Advances in Coatings Technology, Warsaw 2004.

[3] Hryniewicz T.: Technologia powierzchni i powłok. Wydawnictwa Uczelniane PK, Koszalin 1999.

[4] Lenik K., Gauda K., Lenik Z.: Forecasting of durability of waterborne coating in the machine industry. The Worldwide Journal of Achievements in Material and Manufacturing Engineering 37(2)/2009, 102-109.

[5] Miodek A.: Zabezpieczenie antykorozyjne wielkogabarytowych konstrukcj stalowych w aspekcie analizy kosztowej. Lakiernictwo Przemysłowe 6/2001, $12-19$.

[6] PN-EN ISO 12944-1:2001 Farby i lakiery - Ochrona przed korozją konstrukcji stalowych za pomoca ochronnych systemów malarskich.

[7] PN-EN ISO 9223:2012 Ochrona materiałów metalowych przed korozją ryzyko korozji w warunkach atmosferycznych - klasyfikacja, określanie i ocena korozyjności atmosfery.

[8] Popko A.: Multilayer neural network for visual object identification. International Conference on Humanity and Social Science. Guangzhou 2014.

[9] Popko A., Gauda K.: Sztuczna sieć neuronowa jako innowacyjne narzędzie wspomagania doboru powłok ochronno-dekoracyjnych. Edukacja - Technika Informatyka 1(23)/2018, 77-82.

[10] Popko A., Jakubowski M., Wawer R.: Membrain neural network for visua pattern recognition, Advances In Science and Technology. Postępy Nauki i Techniki 7(18)/2013, 54-59.

[11] Rodzynkiewicz-Rudzińska J. (Ed.): Powłoki malarsko-lakiernicze. Poradnik Wydawnictwa Naukowo-Techniczne, Warszawa 1983.

[12] Tadeusiewicz R.: Sieci Neuronowe. Problemy Współczesnej Nauki i Techniki, Informatyka. Akademicka Oficyna Wydawnicza, Warszawa 1999.

[13] Zinowicz Z., Gauda K.: Powłoki organiczne w technice antykorozyjnej. Wydawnictwo Politechniki Lubelskiej, Lublin 2003

[14] Zubielewicz M.: Działanie ochronne powłok z farb wodorozcieńczalnych w zależności od rodzaju pigmentów antykorozyjnych. Lakiernictwo przemysłowe $1 / 2002,15-17$
D.Sc. Eng. Artur Popko

e-mail: artur.popko@wsei.lublin.pl

Associate Professor WSEI, Ph.D. D.Sc. Eng. Artur Popko defended his doctoral thesis at the Faculty of Working Machines and Transport of the Poznan University of Technology in 1997. He defended his habilitation thesis at the Faculty of Production Engineering of the University of Life Sciences in Lublin in 2012. He developed, among others methods of computer-aided processes using systems based on artificial neural networks.

ORCID ID: 0000-0001-8882-0545

\section{e-mail: konrad.gauda@wsei.lublin.pl}

A graduate of doctoral studies organized at the Faculty of Mechanical Engineering of the Lublin University of Technology. His scientific interests mainly include surface engineering and computer-aided learning process. He is the author or co-author of 2 monographs and over 30 articles in the field of organic coatings research and the use of computer science in technology and education.

\section{ORCID ID: 0000-0002-7300-6978}

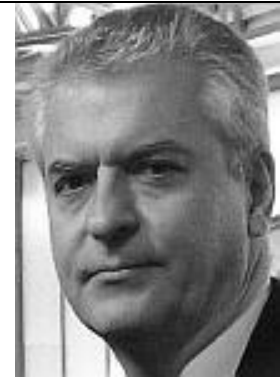

otrzymano/received: 29.08 .2019

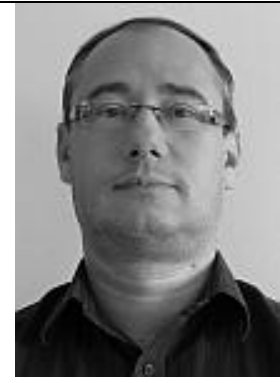

przyjęto do druku/accepted: 06.12.2019 